\title{
Efektifitas Ceramah terhadap Pengetahuan Kader Kesehatan tentang Penyakit Talasemia di Kecamatan Pekuncen dan Kecamatan Sumbang Kabupaten Banyumas
}

\author{
Dwi Sarwani SR ${ }^{1}$, Nunung Nurhayati ${ }^{2}$, Supriyanto ${ }^{2}$ \\ ${ }^{1}$ Fakultas Kedokteran dan Ilmu ilmu Kesehatan Universitas Jenderal Soedirman \\ ${ }^{2}$ Fakultas Sains dan Teknik Universitas Jenderal Soedirman \\ Corresponding author, email: email: dwisarwanisr@yahoo.com
}

\begin{abstract}
Background: One of the causes of the ineffective preventing of Thalassemia and getting more cases in Pekuncen and Sumbang sub district Banyumas was inadequate knowledge of the disease. Health volunteers had an important role to the distribution of information about thalassemia to the people. This research was aimed to observe the effectiveness of lecture method in improving knowledge of health volunteers on Thalassemia in Sumbang and Pekuncen sub district.

Methods: The researcher applied quasi experiment through pretest and posttest design in her research. The population covered the active health volunteers in Sumbang and Pekuncen Sub districts consisted of 64 people who met the criteria. For analyzing the data, the researcher used univariate and bivariate (Wilcoxon test).

Results and conclusion: The research showed that there was a different knowledge before and after lecture activity, the average score of knowledge before getting the treatment was 10.82 and it improved into 12.18 after the lecture session. There was $60.7 \%$ volunteers that was improved their knowledge after obtaining lecture session on thalassemia.
\end{abstract}

Keywords: thalassemia, health volunteer, lecture method

\begin{abstract}
ABSTRAK
Latar belakang: Pengetahuan yang belum memadai diduga menjadi salah satu penyebab upaya pencegahan penyakit talasemia belum bisa berjalan dan hal ini berdampak pada terus bertambahnya kasus talasemia di Kecamatan Pekuncen dan Sumbang Kabupaten Banyumas. Kader kesehatan menjadi salah satu ujung tombak untuk melakukan upaya penyebaran informasi pada masyarakat. Penelitian ini bertujuan untuk mengetahui efektifitas metode ceramah dalam meningkatkan pengetahuan kader kesehatan tentang talasemia di Kecamatan Sumbang dan Pekuncen.

Metode: Jenis penelitan merupakan penelitian eksperimen semu (Quasi experimental) dengan rancangan pre-test and post-test design. Populasi yaitu kader kesehatan yang aktif di Kecamatan Sumbang dan Pekuncen. Jumlah sampel yaitu 64 yang memenuhi kriteria yang telah ditetapkan. Analisis secara univariat dan bivariat (uji Wilcoxon).

Hasil dan kesimpulan: Hasil uji menunjukkan adanya perbedaan pengetahuan sebelum dan sesudah kegiatan ceramah, rata-rata skor pengetahuan sebelum diberi ceramah 10,82 meningkat menjadi 12,18 . Ada sebanyak $60,7 \%$ kader yang meningkat pengetahuannya setelah diberi ceramah tentang talasemia.
\end{abstract}

Kata Kunci : talasemia, kader kesehatan, metode ceramah

\section{PENDAHULUAN}

Talasemia adalah penyakit kelainan darah secara genetik akibat kekurangan atau penurunan produksi/pembentukkan hemoglobin. Talasemia adalah salah satu gangguan genetik hemoglobin akibat adanya gangguan sintesis rantai globin. ${ }^{1}$ 
Talasemia merupakan penyakit anemia hemolitik herediter yang diturunkan secara resesif. ${ }^{2}$ Anemia hemolitik adalah suatu keadaan dimana kadar hemoglobin kurang dari nilai normal akibat kerusakan sel eritrosit yang lebih cepat dari kemampuan sumsum tulang untuk menggantinya. ${ }^{3}$ World Health Organization (WHO) mengatakan bahwa $5 \%$ dari jumlah populasi di dunia adalah carrier secara genetik kelainan hemoglobin. WHO melaporkan bahwa 370.000 penderita talasemia lahir setiap tahun. UNICEF (1996) memperkirakan bahwa 29,7 juta pembawa beta talasemia berada di India dan sekitar 10.000 bayi lahir dengan beta talasemia homozigot. ${ }^{4}$ Berdasarkan laporan riset kesehatan dasar (2007) prevalensi nasional talasemia di Indonesia adalah $0,1 \% .^{5}$

Menurut laporan Rotary International Indonesian (2010), di Banyumas pada tahun 2008 terdapat 44 penderita talasemia. Jumlah ini bertambah menjadi 65 orang pada tahun 2009 atau meningkat sebesar 32,3\%. Sementara itu pada tahun 2010, Yayasan Talasemia Indonesia (YTI) Cabang Banyumas mencatat bahwa jumlah penderita yang terdaftar mencapai 100 orang atau meningkat sebesar $53,85 \%$. Pada data terakhir sampai 30 November 2011 dilaporkan bahwa ada 153 penderita atau terjadi peningkatan sebesar $53 \%$. Jumlah ini mungkin lebih besar lagi karena banyak penderita talasemia yang belum terdeteksi. ${ }^{6}$

Jumlah penderita talasemia beta mayor yang terdaftar di Rumah Sakit Umum Daerah (RSUD) Kabupaten Banyumas pada bulan Maret 2012 sebanyak 161 orang dimana setiap tahunnya selalu bertambah. ${ }^{7}$ Jumlah penderita talasemia yang terdaftar di yayasan talasemia Indonesia cabang Banyumas sampai tahun 2011 sebanyak 164 orang yang terdiri pasien-pasien dari RSUD Banyumas dan RS lain. ${ }^{6}$ Berdasarkan data tersebut, ada 2 kecamatan di Kabupaten Banyumas yang penderitanya cukup banyak dalam dua tahun terakhir yaitu Kecamatan Sumbang dan Pekuncen.

Kecamatan Sumbang dan Kecamatan Pekuncen Kabupaten Banyumas merupakan kecamatan dengan jumlah penderita Talasemia yang paling banyak di Kabupaten Banyumas. Sebagian besar penderita Talasemia di Kabupaten Banyumas adalah anak-anak dengan rentang umur antara 1-10 tahun (87,5\%). Penderita talasemia yang terdaftar di YTI cabang Banyumas sebagian besar juga dari sosial ekonomi menengah ke bawah (95\%). ${ }^{6}$

Kader kesehatan di Kecamatan Sumbang dan Pekuncen masih mempunyai pengetahuan dan pemahaman yang kurang tentang penyakit talasemia. Selain kader, masyarakat masih mempunyai persepsi yang salah mengenai penyakit talasemia. Masyarakat juga belum banyak mengenal apa itu penyakit talasemia. Pengetahuan yang belum memadai diduga menjadi salah satu faktor penyebab tingginya kasus talasemia sehingga diperlukan upaya pendidikan masyarakat. Alternatif metode pendidikan kesehatan yang bisa digunakan adalah metode ceramah. Metode ceramah selain sederhana juga efektif dalam upaya penyampaian informasi secara cepat kepada kelompok sasaran yang cukup besar. ${ }^{8}$

Keberhasilan upaya pendidikan kesehatan dengan metode ceramah dipengaruhi oleh kemampuan penceramah memahami karakteristik dan struktur sosial masyarakat. Salah satu ujung tombak untuk melakukan upaya penyebaran informasi adalah melalui kader kesehatan karena mereka berasal dari masyarakat itu sendiri, sehingga mampu menyebarkan informasi kepada masyarakat dengan baik. ${ }^{9}$

Berdasarkan hal tersebut penulis ingin mengetahui efektivitas metode ceramah untuk meningkatkan pengetahuan kader di Kecamatan Pekuncen dan Kecamatan Sumbang.

\section{METODE}

Lokasi penelitian ini adalah di Kecamatan Pekuncen dan Kecamatan Sumbang Kabupaten Banyumas. Jenis penelitian yang digunakan adalah penelitian eksperimen semu (Quasi experimental) dengan rancangan pre-test and post-test 
design. Responden dalam penelitian diberi pre test selama 15 menit dan kemudian dilanjutkan dengan pemberian ceramah tentang talasemia, selanjutnya responden diberi post test selama 15 menit. Kegiatan dilaksanakan pada tanggal 2 Juli 2013 di Kecamatan Pekuncen dan 4 Juli 2013 di Kecamatan Sumbang. Pemberian ceramah dilakukan oleh 3 narasumber yaitu mengenai epidemiologi talasemia, pencegahan talasemia dan perawatan penderita talasemia. Populasi penelitin adalah semua kader kesehatan di Kecamatan Pekuncen, sedangkan sampel dalam penelitian adalah kader kesehatan yang terpilih sesuai dengan kriteria inklusi dan eksklusi yaitu sebanyak 64 sampel. Kriteria inklusi yaitu kader aktif dalam 3 tahun terakhir, bisa membaca dan menulis. Kriteria eksklusi yaitu tidak hadir saat kegiatan berlangsung. Analisis data secara univariat dan bivariat. Uji Wilcoxon digunakan untuk mengetahui ada tidaknya perbedaan pengetahuan sebelum dan sesudah kegiatan.

\section{HASIL PENELITIAN DAN PEMBAHASAN}

a) Karakteristik Responden sebagai berikut:

Gambaran karakteristik responden menurut umur, pendidikan dan pekerjaan

Tabel 1. Karakteristik Kader di Kecamatan Pekuncen dan Kecamatan Sumbang

\begin{tabular}{|c|c|c|c|c|}
\hline No & Variabel & Kategori & Jumlah & $\begin{array}{c}\text { Persentase } \\
(\%)\end{array}$ \\
\hline 1. & Umur (tahun) & $\begin{array}{l}\text { Usia termuda } 27 \text { tahun, usia } \\
\text { tertua } 57 \text { tahun, rata-rata usia } \\
\text { responden } 40,8 \text { tahun }\end{array}$ & & \\
\hline \multirow[t]{2}{*}{2.} & Pendidikan & $\begin{array}{ll}\text { a. } & \text { Rendah (Tidak sekolah, SD, } \\
\text { SMP) }\end{array}$ & 33 & 51,6 \\
\hline & & $\begin{array}{l}\text { b. Tinggi (SMA, Perguruan } \\
\text { Tinggi) }\end{array}$ & 31 & 48,4 \\
\hline \multirow[t]{2}{*}{4.} & Pekerjaan & $\begin{array}{l}\text { a. Tidak bekerja (Ibu rumah } \\
\text { tangga) }\end{array}$ & 46 & 71,9 \\
\hline & & $\begin{array}{l}\text { b. Bekerja (PNS, TNI/ABRI, } \\
\text { Polisi, swasta, wiraswasta, } \\
\text { petani, buruh) }\end{array}$ & 18 & 28,1 \\
\hline
\end{tabular}

Tabel 1 menunjukkan bahwa rata-rata umur responden dalam penelitian ini adalah 40,8 tahun, sebagian besar berpendidikan rendah $(51,6 \%)$ dan sebagai ibu rumah tangga $(71,9 \%)$.

\section{b) Pengetahuan Kader}

Hasil pengukuran tingkat pengetahuan kader sebelum dan sesudah kegiatan ceramah disajikan pada Tabel 2. 
Tabel 2. Hasil Pengukuran Tingkat Pengetahuan Kader Sebelum Kegiatan dan Sesudah Kegiatan

\begin{tabular}{|c|c|c|c|c|c|}
\hline \multirow[b]{2}{*}{ No } & \multirow[b]{2}{*}{ Pernyataan } & \multicolumn{2}{|c|}{ Pre test } & \multicolumn{2}{|c|}{ Post test } \\
\hline & & $\begin{array}{l}\text { Salah } \\
(\%)\end{array}$ & $\begin{array}{c}\text { Benar } \\
(\%)\end{array}$ & $\begin{array}{l}\text { Salah } \\
(\%)\end{array}$ & $\begin{array}{l}\text { Benar } \\
(\%)\end{array}$ \\
\hline 1. & $\begin{array}{l}\text { Talasemia adalah } \\
\text { pembentukan sel darah merah. }\end{array}$ & 12,5 & 87,5 & 3,6 & 96,4 \\
\hline 2. & $\begin{array}{l}\text { Talasemia terjadi akibat ketidakmampuan } \\
\text { sumsum tulang membentuk protein yang } \\
\text { berfungsi untuk memproduksi hemoglobin. }\end{array}$ & 23,2 & 76,8 & 1,8 & 98,2 \\
\hline 3. & Talasemia merupakan penyakit keturunan. & 17,9 & 82,1 & 1,8 & 98,2 \\
\hline 4. & $\begin{array}{l}\text { Seseorang dengan pembawa sifat talasemia } \\
\text { tidak berisiko memiliki keturunan dengan } \\
\text { talasemia. }\end{array}$ & 39,3 & 60,7 & 25,0 & 75,0 \\
\hline 5. & Penderita talasemia dapat mengalami anemia. & 16,1 & 83,9 & 0,0 & 100,0 \\
\hline 6. & $\begin{array}{l}\text { Wajah pucat merupakan gejala anemia pada } \\
\text { penderita talasemia. }\end{array}$ & 7,1 & 92,9 & 0,0 & 100,0 \\
\hline 7. & $\begin{array}{l}\text { Anak yang menderita talasemia berat akan } \\
\text { tumbuh lebih lambat. }\end{array}$ & 14,3 & 85,7 & 1,8 & 98,2 \\
\hline 8. & $\begin{array}{l}\text { Anak yang menderita talasemia berat akan } \\
\text { mencapai pubertas lebih lambat. }\end{array}$ & 17,9 & 82,1 & 10,7 & 89,3 \\
\hline 9. & $\begin{array}{l}\text { Tes laboratorium untuk mengetahui anak } \\
\text { menderita talasemia tidak dapat dilakukan saat } \\
\text { anak masih dalam kandungan. }\end{array}$ & 37,5 & 62,5 & 28,6 & 71,4 \\
\hline 10. & $\begin{array}{l}\text { Pencegahan talasemia dapat dilakukan } \\
\text { melalui konsultasi pranikah. }\end{array}$ & 37,5 & 62,5 & 7,1 & 92,9 \\
\hline 11. & $\begin{array}{l}\text { Bersentuhan dengan penderita talasemia } \\
\text { menjadi salah satu cara penularan penyakit } \\
\text { talasemia }\end{array}$ & 17,9 & 82,1 & 8,9 & 91,1 \\
\hline 12. & $\begin{array}{l}\text { Tanpa perawatan dan pengobatan penderita } \\
\text { talasemia berat dapat tetap hidup secara } \\
\text { normal. }\end{array}$ & 60,7 & 39,3 & 66,1 & 33,9 \\
\hline 13. & $\begin{array}{l}\text { Penderita talasemia berat hanya melakukan } \\
\text { pemeriksaan dan perawatan ke pelayanan } \\
\text { kesehatan jika penyakitnya sudah sangat } \\
\text { parah. }\end{array}$ & 14,3 & 85,7 & 17,9 & 82,1 \\
\hline 14. & $\begin{array}{l}\text { Penyuluhan tentang pewarisan penyakit } \\
\text { kepada keturunannya, diperlukan bagi } \\
\text { keluarga dengan riwayat talasemia untuk } \\
\text { menentukan resiko memiliki anak yang } \\
\text { menderita talasemia. }\end{array}$ & 19,6 & 80,4 & 8,9 & 91,1 \\
\hline
\end{tabular}

Hasil pengukuran pengetahuan sebelum intervensi (pre test) menunjukkan masih ada beberapa kader yang belum paham tentang talasemia, yaitu seperti pertanyaan nomer (4) seseorang dengan pembawa sifat tidak berisiko untuk memiliki keturunan talasemia, nomer (9) tes laboratorium untuk deteksi talasemia dapat dilakukan saat anak masih dalam kandingan, nomer (12) pencegahan talasemia dapat dilakukan dengan konsultasi pra nikah. Pada hasil pengukuran pengetahuan sesudah intervensi (post test) menunjukkan masih ada 1 pertanyaan masih dijawab secara tidak tepat yaitu nomor (12) tanpa perawatan dan pengobatan penderita talasemia berat dapat tetap hidup secara normal. Memang pertanyaan nomer 12 ini pertanyaan negatif, jadi kemungkinan kader kurang teliti saat membacanya.

Berikut ini grafik yang menunjukkan perubahan skor rata-rata pengetahuan kader sebelum dan sesudah kegiatan. 


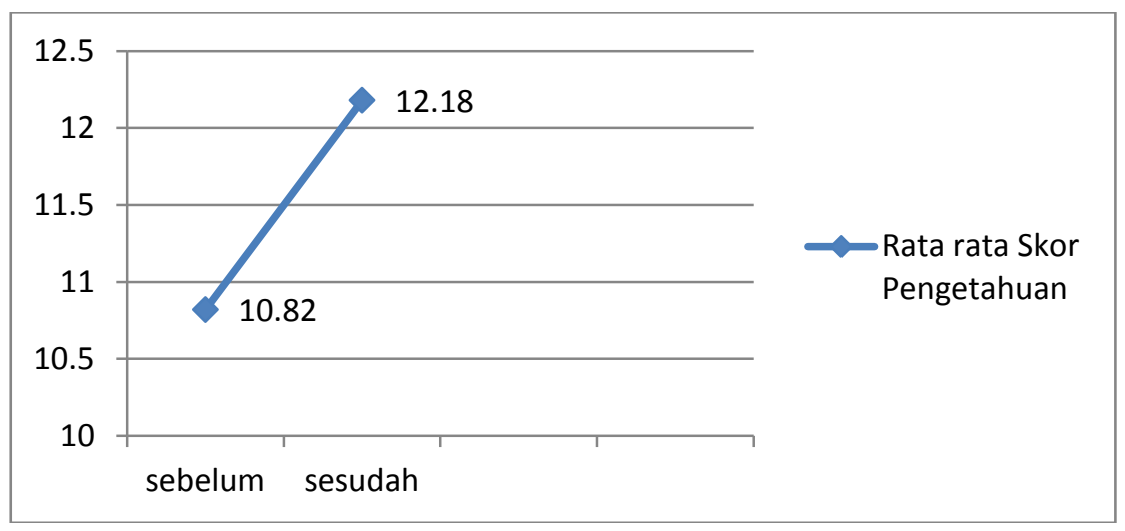

Gambar 1. Grafik Perubahan Pengetahuan Sebelum dan Sesudah Kegiatan

Hasil analisa data yang diperoleh dari metode ceramah menunjukkan adanya perubahan tingkat pengetahuan. Hal ini terlihat dari nilai rata-rata pengetahuan sebelum intervensi yaitu 10,82 kemudian meningkat menjadi 12,18. Berikut ini disajikan data hasil analisis uji beda rata-rata skor pengetahuan sebelum dan sesudah intervensi.

Tabel 3. Perbedaan Pengetahuan Sebelum dan Sesudah Kegiatan Ceramah

\begin{tabular}{llll}
\hline \multicolumn{1}{c}{ Pengetahuan } & Nilai rata-rata & Nilai Z & $p$ \\
\hline Sebelum ceramah & 10,82 & $-3,862$ & 0,000 \\
Sesudah ceramah & 12,18 & & \\
\hline
\end{tabular}

Hasil analisis menunjukkan ada 34 kader yang meningkat pengetahuannya. Jadi terjadi peningkatan pengetahuan sebelum dan sesudah ceramah sebesar $60,7 \%$. Hasil uji statistik dengan menggunakan uji Wilcoxon diperoleh nilai $p=0,001(<0,05)$, maka dapat disimpulkan bahwa terdapat perbedaan pengetahuan kader sebelum dan sesudah diberi ceramah tentang talasemia.

Hasil penelitian menunjukkan ada perbedaan bermakna secara uji statistik skor pengetahuan kader sebelum dan sesudah intervensi dengan nilai $p=0,000$. Hal ini menunjukkan bahwa intervensi berupa ceramah efektif meningkatkan pengetahuan kader kesehatan tentang talasemia. Penelitian ini sejalan dengan penelitian yang dilakukan oleh Patompo dan Sukirman (2011) tentang Pengaruh Penyuluhan Kesehatan Metode Ceramah tentang Tanaman Obat Keluarga Terhadap Perubahan Pengetahuan dan Sikap Kader Kesehatan yang menunjukkan bahwa terdapat perbedaan pengetahuan pada kader kesehatan setelah diberi penyuluhan dengan metode ceramah. ${ }^{10}$ Pada hasil penelitian ini diketahuan peningkatan pengetahuan tidak terlalu banyak dimungkinkan karena sebagian besar kader masih berpendidikan rendah. Wijayanti (2011) menyatakan makin tinggi tingkat pendidikan seseorang, maka semakin mudah menerima informasi sehingga semakin banyak pengetahuan yang dimiliki. ${ }^{11}$ Harsono dan Samsudi (2009) menyatakan sebaiknya metode ceramah disertai dengan media pembelajaran yang menarik sehingga tidak membosankan. ${ }^{12}$

Notoatmodjo (2003) mengemukakan bahwa metode ceramah adalah salah satu metode yang sering digunakan untuk kelompok besar dengan jumlah peserta lebih dari sering digunakan untuk kelompok besar dengan jumlah peserta lebih dari yang menyenangkan, interaktif dan menggunakan bahasa yang mudah dipahami. ${ }^{8}$ Peserta ceramah juga sangat antusias dengan materi yang disampaikan, didukung dengan adanya diskusi dan tanyajawab oleh kader. Situasi saat pelaksanaan ceramah juga 
mendukung keberhasilan metode ini, yaitu tenang dan tidak ada kader yang membawa anak kecil. Kader menyatakan bahwa kemampuan narasumber membangun suasana membuat responden tertarik untuk menyimak materi yang disampaikan sehingga responden tidak merasa bosan.

Sheffer et al (2009) menyatakan training kepada tenaga kesehatan dengan metode ceramah dapat meningkatkan pengetahuan dan merubah sikap kearah positif. ${ }^{13}$ Hasil penelitian Tarigan (2007) menyatakan metode ceramah, diskusi dan modul dapat meningkatkan pengetahuan tokoh masyarakat tentang malaria. ${ }^{14}$

Pendidikan kesehatan dengan metode ceramah tentang talasemia disimpulkan dapat meningkatkan pengetahuan kader kesehatan di Kecamatan Pekuncen dan Sumbang. Kader kesehatan yang merupakan ujung tombak penyebaran informasi kepada masyarakat diharapkan dapat membagi informasi yang diperoleh kepada masyarakat.

\section{SIMPULAN}

Responden dalam penelitian ini rata-rata berumur 40,8 tahun, sebagian besar berpendidikan rendah dan sebagai ibu rumah tangga. Ada perbedaan tingkat pengetahuan responden sebelum dan sesudah diberi ceramah tentang talasemia, skor pengetahuan sebelum diberi ceramah 10,82 meningkat menjadi 12,18. Ada sebanyak $60,7 \%$ kader yang meningkat pengetahuannya setelah diberi ceramah tentang talasemia.

\section{UCAPAN TERIMA KASIH}

Terimakasih kami sampaikan kepada LPPM Unsoed dan kader kesehatan di Kecamatan Pekuncen dan Sumbang. Kegiatan ini adalah bagian dari Kegiatan Iptek Bagi Masyarakat (IbM) yang dibiayai oleh DP2M Dikti Nomor DIPA023.04.1.673453/2013.

\section{DAFTAR PUSTAKA}

1. Mehta, A. dan A.V. Hoffbrand; alih bahasa, Hartanto, H., Hematology at a Glace. Erlangga, Jakarta, 2008.

2. Suriadi dan R. Yuliani, Asuhan Keperawatan Pada Anak, Penebar Swadaya, Jakarta, 2006.

3. Sudoyo, A.W., B. Setiyohadi, I. Alwi, M. Simadibrata, dan S. Setiati. IImu Penyakit Dalam, Pusat Penerbitan IImu Penyakit Dalam FK UI, Jakarta, 2006.

4. Shivashankara, A. R., R. Jailkhani, dan A. Kini, Hemoglobinopathies in Dharwad, North Karnataka: A Hospital-Based Study, Journal of Clinical and Diagnostic Research, Vol. 2, Pp. 593-599, 2008.

5. Pusat Komunikasi Publik, Sekjen Kemenkes RI. Thalasemia Bukan Penyakit Menular. http://www.sehatnegeriku.com. Diakses 12 Desember 2013.

6. Yayasan Talasemia Indonesia Cab. Banyumas, Data Penderita Talasemia di YTI, 2011.

7. RSUD Kabupaten Banyumas, Laporan Penderita Talasemia tahun 2012, 2012.

8. Notoatmodjo, Pendidikan dan Perilaku Kesehatan, Rineka Cipta, Jakarta, 2003.

9. Trisnawati Azizah dan Faizah Rahayuningsih. Pelatihan Peningkatan Kemampuan Kader Kesehatan Dalam Penanganan TBC di Wilayah Kerja Puskesmas Gemolong II Sragen. Warta, Vol/Issue: 11(2). Pp. 150-158, 2008.

10. Patompo dan Sukirman, Pengaruh Penyuluhan Kesehatan Metode Ceramah tentang Tanaman Obat Keluarga terhadap Perubahan Pengetahuan dan Sikap Kader Kesehatan, Jurnal Pendidikan Dokter, Vol/Issue: 7(8), 2011.

11. Wijayanti, D., Hubungan antara Pengetahuan dengan Sikap lbu Bersalin terhadap Rawat Gabung di Polindes Mekar Sari Desa Bebengan Kecamatan Boja Kabupaten Kendal, Jurnal IImu Kesehatan, Vol/Issue: 1(2), 2011. 
12. Harsono, B dan Samsudi, S., Perbedaan Hasil Belajar antara Metode Ceramah Konvensional dengan Ceramah Bebantuan Media Animasi pada Pembelajaran Kompetensi Perakitan dan Pemasangan Sistem Rem, Jurnal Pendidikan Teknik Mesin, Vol/Issue: 9(02). Pp. 71-79, 2009.

13. Sheffer, C.E., Barone, C.P. \& Anders, M.E., Training Health Care Providers in the Treatment of Tobacco Use and Dependence: Pre-and Post Training Result, J Eval Clinic Pract, Vol. 15. Pp. 607-613, 2009.

14. Tarigan. J., Pengaruh Metode Ceramah, Diskusi dan Modul terhadap Peningkata Pengetahuan dan Sikap Tokoh Masyarakat dalam Pencegahan Malaria di Kecamatan Lau Baleng Kabupaten Karo, Tesis, Universitas Gadjah Mada, Yogyakarta, 2007. 
